Abstracta Iranica Iranica

Revue bibliographique pour le domaine irano-aryen

Volume 27 | 2006

Comptes rendus des publications de 2004

\title{
" Afghanistan: From Here to Eternity ». Parameters, volume 34, (2004), pp. 4-15.
}

\section{Anicée Van Engeland-Nourai}

\section{OpenEdition}

1 Journals

\section{Édition électronique}

URL : http://journals.openedition.org/abstractairanica/6074

DOI : 10.4000/abstractairanica.6074

ISSN : 1961-960X

Éditeur :

CNRS (UMR 7528 Mondes iraniens et indiens), Éditions de l'IFRI

\section{Édition imprimée}

Date de publication : 15 mai 2006

ISSN : 0240-8910

\section{Référence électronique}

Anicée Van Engeland-Nourai, « «Afghanistan: From Here to Eternity ». Parameters, volume 34, (2004), pp. 4-15. », Abstracta Iranica [En ligne], Volume 27 | 2006, document 224, mis en ligne le 02 janvier 2007, consulté le 25 septembre 2020. URL : http://journals.openedition.org/abstractairanica/6074 ; DOI : https://doi.org/10.4000/abstractairanica.6074

Ce document a été généré automatiquement le 25 septembre 2020.

Tous droits réservés 


\title{
« Afghanistan: From Here to Eternity ». Parameters, volume 34, (2004), pp. 4-15.
}

\author{
Anicée Van Engeland-Nourai
}

1 Loin de crier victoire sur le travail de l'armée américaine en Afghanistan, l'article fait le bilan sur la présence américaine et les problèmes rencontrés sur le terrain. C'est un article réaliste qui présente les objectifs, les stratégies, les phases d'interventions, les critiques de ces actions et les succès de l'armée américaine. L'A. laisse aux organisations non gouvernementales et aux Nations Unies le soin de s'occuper de la reconstruction.

2 Selon lui, le rôle de l'armée américaine se limite à détruire al Qaeda, ce qui est un objectif clair. Il rejette l'argument selon lequel l'Afghanistan serait un nouveau Vietnam et souligne les succès obtenus comme la chute des Talibans.

3 Un programme d'action est établi pour le futur : il faut désormais s'occuper des chefs de guerre, des chefs de tribus, du trafic de drogue, des dommages écologiques dus aux guerres successives, des mines, de l'éducation et des droits de l'homme. L'A. estime que c'est aux dirigeants afghans que revient le soin d'établir et de diriger ces missions et non à l'armée américaine dont le seul objectif est la guerre et la destruction d'al Qaeda. Sa conclusion est que les Américains n'avaient pas d'autres choix que d'attaquer l'Afghanistan et que les résultats obtenus jusqu'ici sont honnêtes.

\section{INDEX}

Thèmes : 4.4. Histoire de l'Afghanistan (à partir de 1747) 
AUTEURS

ANICÉE VAN ENGELAND-NOURAI

Paris 